\title{
TOPOLÓGIAI OPTIMALIZÁLÁSI FELADATOK ALAPVETŐ SAJÁTOSSÁGAI ABAQUS VÉGESELEMES PROGRAMRENDSZERBEN
}

\author{
Gönczi Dávid \\ adjunktus, Miskolci Egyetem, Müszaki Mechanikai Intézet \\ 3515 Miskolc, Miskolc-Egyetemváros, e-mail: mechgoda@uni-miskolc.hu
}

\begin{abstract}
Absztrakt
Jelen cikk a modern mérnöki gyakorlatban egyre többet alkalmazott optimalizálási technikák, azon belül is részletesebben a topológiai optimalizálási problémák kereskedelmi végeselemes szoftverekkel való megoldásával foglalkozik. Bemutatásra kerülnek az Abaqus általános célú VEM szoftveren belül az optimalizálási eljárás föbb jellemzői. Áttekintjük a modern mérnöki anyagok, mint például a kompozitok, avagy a funkcionálisan gradiens anyagok vizsgálatának lehetöségeit is egyszerü mintapéldákon keresztül.
\end{abstract}

Kulcsszavak: topológiai optimalizálás, VEM, Abaqus

\begin{abstract}
This paper deals with the optimisation methods used in recent engineering practice, more precisely the utilisation of topology optimisation in commercial finite element software. The main aspects of topology optimisation are presented in Abaqus CAE. The main steps of the optimisation of composite and functionally graded materials are outlined.
\end{abstract}

Keywords: topology optimisation, FEM, Abaqus

\section{Bevezetés}

Az utóbbi évtizedekben a számítástechnika fejlődésével a termékek tervezésének és fejlesztésének eszköztára jelentősen kibővült. A CAD/CAM rendszerek elterjedése és fejlödése, a numerikus szimulációk gyorsabbá és hatékonyabbá válása mellett megjelentek olyan anyagok és technológiák is, amelyek a klasszikus tervezési felfogást bizonyos területeken felváltották. A kompozitokban az alkotóelemeket szilárd fázisban egyesítik, így éles határfelületek jelennek meg, amelyek korlátozzák alkalmazhatóságukat, hiszen például magasabb hőmérsékletü közegben repedések alakulhatnak ki az éles határfelületek mentén a komponensek eltérő hőtágulási együtthatói miatt. Ezzel szemben a funkcionálisan gradiens anyagok olyan anyagok, amelyekben az anyagi összetétel, és ezzel együtt az anyagi tulajdonságok fokozatosan változnak a térben - legtöbb esetben egy irányban, ritkább esetekben két vagy több irányban indokolt. Így például a kiváló mechanikai tulajdonságuk mellett jó hőállósággal is rendelkeznek. Ezen anyagok esetén nem a klasszikus tervezési filozófia érvényesül, miszerint a konstrukcióhoz választunk egy anyagot, és ahhoz hangoljuk a szerkezetet, hanem az anyagot külön a szerkezethez, funkciónak megfelelöen tervezzük. Ezt inverz tervezési szemléletnek nevezzük. 
A termékek tervezési folyamatában, amíg a vázlatból késztermék lesz, számos szempontot kell figyelembe venni, amelyek a termék funkcionalitásától a gyárthatósági, megvalósíthatósági, javíthatósági kérdéseken át egészen a gazdaságossági szempontokig terjedhetnek. A termékek tervezése tehát egy iteratív, többfázisú folyamat, ahol a struktúra elemeinek kialakítása számos tervezési aspektusra hatással van. Néhány évtizede még a hagyományos konstrukciókban egyszerü geometria formákat (síkokat, hengeres felületeket) és ,feature"-ökre törekedtek, de a vásárlói igények és a marketing szempontok, továbbá a funkcionalitás bővülésének következtében ezek megváltoztak. $\mathrm{Az}$ anyagok előzőekben felvázolt fejlődése mellett a gyártástechnológiában is ugrásszerü fejlődés következett be a korszerü számítógép vezérelt megmunkálóközpontok, illetve a anyagporos nyomtatás és az additív technológiák megjelenésével.

A generatív tervezés során egy mesterséges intelligencia a megadott tervezési változók, követelmények és lehetőségek alapján a gépi tanulás eszközeivel felhasználói beavatkozás nélkül generál egy megoldáshalmazt. A módszer nagy előnye, hogy a klasszikus folyamatokhoz képest sokkal több megoldásvázlatot kapunk, amelyek mindegyike megfelel az elöírt feltételeknek.

Az utóbbi évtizedekben a mérnöki optimalizálással foglalkozó könyvek [1-4] és cikkek (mint például a [5-9]) száma ugrásszerúen megemelkedett. Speciális anyagokkal foglalkozó munkákkal is gyakran találkozunk, például funkcionálisan gradiens anyagokra vonatkozóan [10-12], míg kompozitok optimalizációjára [13-15] hozható példaként. Jelen tanulmányban a kereskedelmi végeselemes szoftverekben rendelkezésre álló főbb optimalizációs lehetőségeket szeretnénk áttekinteni.

\section{Az optimalizációs probléma megfogalmazása és főbb típusai}

Az optimalizációs folyamat során a problémát matematikailag meg kell fogalmazni, majd egy megfelelő optimalizációs algoritmus segítségével megoldani. Nemlineáris programozási feladatként az alábbi alakban adható az optimalizációs probléma:

$$
\begin{gathered}
f(x) \rightarrow \max / \min \\
g_{m}(x) \leq 0, m=1,2, \ldots, k, \\
h_{j}(x)=0, \quad j=1,2, \ldots, l, \\
L_{i} \leq x_{i} \leq U_{i}, i=1,2, \ldots, n .
\end{gathered}
$$

ahol $x$ a tervezési változók halmaza, $f(x)$ a tervezési célfüggvények halmaza, amelyek extrémumát keressük, $g(x)$ és $h(x)$ függvények pedig a tervezési egyenlőtlenségi és egyenlőségi feltételek. Sok esetben kijelölhetők bizonyos alsó és/vagy felső korlátok a tervezési változókra vonatkozóan $(L, U)$. A feladat megoldására vonatkozóan két alapvető algoritmus típus különböztethető meg, a determinisztikus (előre definiált lépésekkel haladó) és a sztochasztikus (valószínűségi törvényszerüségeket alkalmazó) algoritmusok.

A modern mérnöki gyakorlatban ezen problémák megoldása numerikus technikákat alkalmazó szoftverek segítségével történik, amelyekből a legelterjedtebbek a végeselem szoftverek. A megoldás menetét mutatja az 1. ábra.

A kereskedelmi forgalomban kapható végeselem szoftverek három nagy kategóriába sorolhatók be. Az általános célú, a tervezőrendszerbe integrált (moduláris) és a célszoftverek. A legsokoldalúbb és legrugalmasabb eszközünk a mérnöki problémák megoldására az általános célú szoftverek, amelyek közül az Abaqus ([16] Dassault System) eszköztárát és az ehhez kapcsolódó Tosca csomagot szeretnénk vizsgálni. Ezen szoftverek felépítésüket tekintve általában három fö részből, azaz modulból 
állnak, amelyek a preprocesszor, azaz az inputfájlszerkesztő grafikus felület, a processzor, ami a tényleges megoldó része a programnak és a posztprocesszor, ami a kiértékelés grafikus felülete. $\mathrm{Az}$ Abaqus esetén a preprocesszor és a posztprocesszor Python programnyelven íródott és külön scripteken keresztük programozható, a processzor nyelve viszont Fortran. A generatív tervezést és az optimalizációt segítő szoftverekröl röviden a [17] tanulmányban olvashatunk.

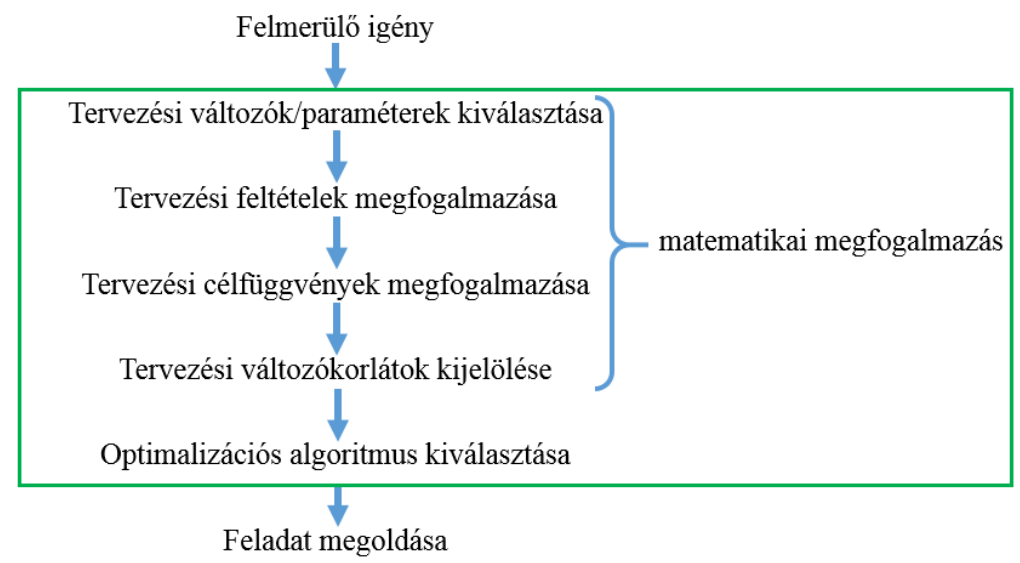

\section{1. ábra. Az optimalizációs feladat}

Az egyszerübb, egy-két tervezési változóval rendelkező feladatok esetében a parametrikus optimalizációt célszerủ alkalmazni. Ezen esetben egy-két paraméter változásának hatását vizsgáljuk, amelyek sokszor könnyen implementálhatók a preprocesszor szkripteken, avagy a processzor inputfájlon keresztüli programozásával.

Szerkezeti optimalizációs problémák esetén a végeselem szoftverekben egy lehetséges kategorizálás szerint három fö típust különböztetünk meg. Topológiai optimalizálás során a tervezési változók az elemek térfogati arányai. Ez lineáris feszültségi analízis esetén magában foglalja az elem sürüségét, a rugalmassági moduluszát (0-1 közötti értékekkel) és a tervezési tartományon belüli elemek kapcsolatát. A 2. ábra szemlélteti egy jármü felfüggesztésének egy elemére vonatkozó optimalizálási feladatát [16], ahol a térfogat csökkentése volt a cél, miközben a feszültségeket egy bizonyos előírt szint alatt tartjuk és maximalizáljuk a szerkezet merevségét. A feladat megoldásának elörehaladásával a térfogat 43\%-kal lecsökkenthető.

Alakoptimalizáció esetén a tervezési változó a tervezési tartomány határa. Sok esetben a tervezés utolsó fázisában, amikor az alkatrész geometriájának nagy része már fix, alkalmazzák néhány felület módosítására. Erre láthatunk egy példát a 3. ábrán, ahol a megjelölt terület feszültségkoncentrációjának csökkentése volt a cél.

A méretoptimalizáció olyan szerkezeti optimalizációs eljárás, ahol a vizsgált rendszer elemeinek valamilyen méreti jellemzőjét változtatva keressük az optimális megoldást. Ez lehet rudak esetén a rúd keresztmetszete (pl. rácsos tartókban) avagy héjak esetén a vastagság. Általánosítása a topometriai optimalizáció, ahol elemenként adódhatnak a tervezési változó vektorának elemei.

Ezeken kívül megkülönböztetünk további speciális eljárásokat is. Az eljárás kiválasztásánál sokféle szempontot kell figyelembe venni. A 4. ábrán látható például egy jármüipari optimalizációs probléma, ahol a karosszéria alakjának módosítása volt a cél [18]. Ebben az esetben a szabadformájú (freeform) optimalizálási módszer, amely az alakoptimalizálás egy kiterjesztett módszere adta a legkisebb tömegủ, míg a topometriával kombinált vizsgálata adta a legnagyobb torziós ellenállású konstrukciót. Ebben az esetben a topológia optimalizálásból kerültek ki a kevésbé kedvező változatok. 

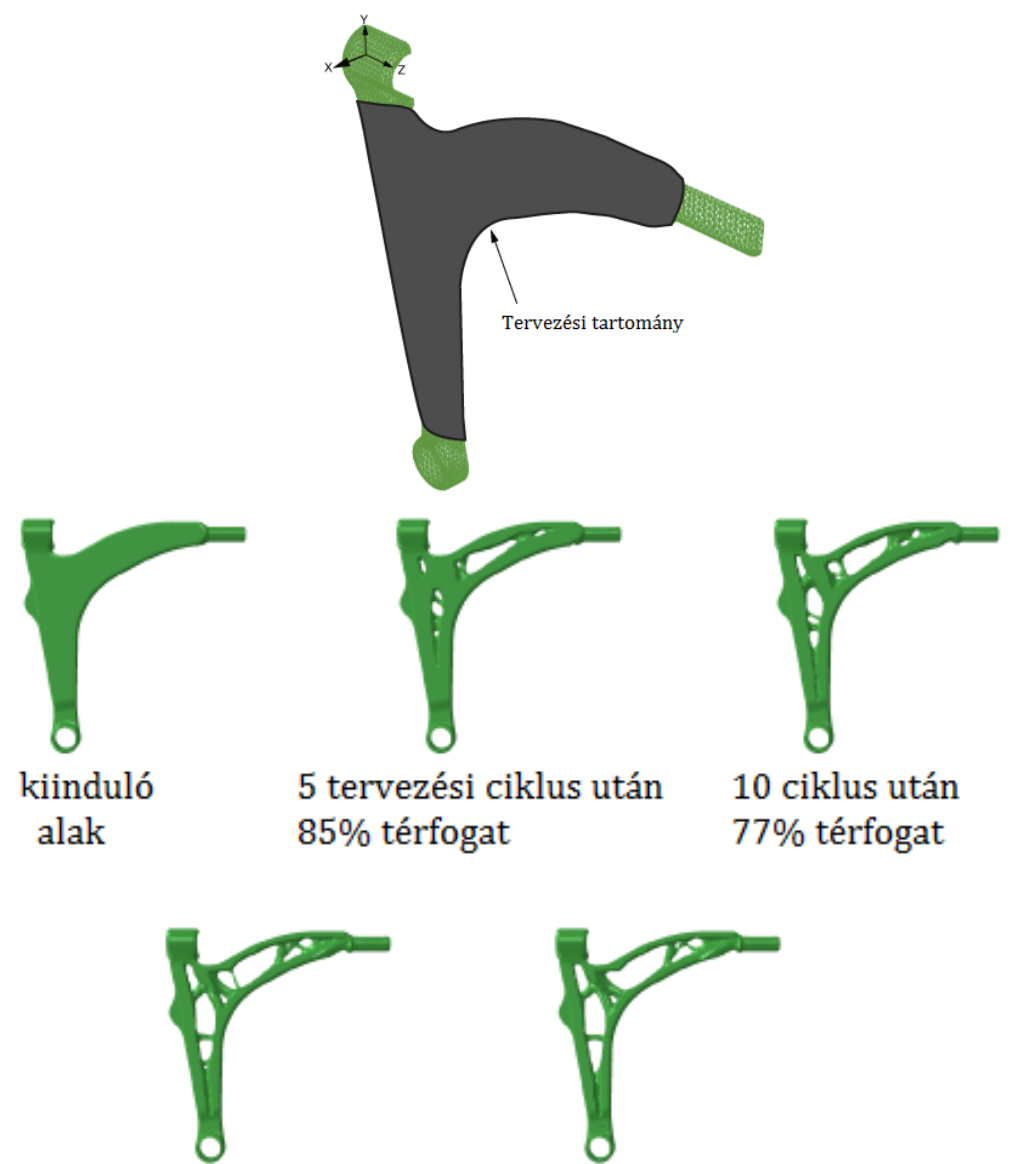

15 ciklus után, $61 \%$ térfogat 17 ciklus után, $57 \%$ térfogat

2. ábra. Autóalkatrész topológiai optimalizálási példája

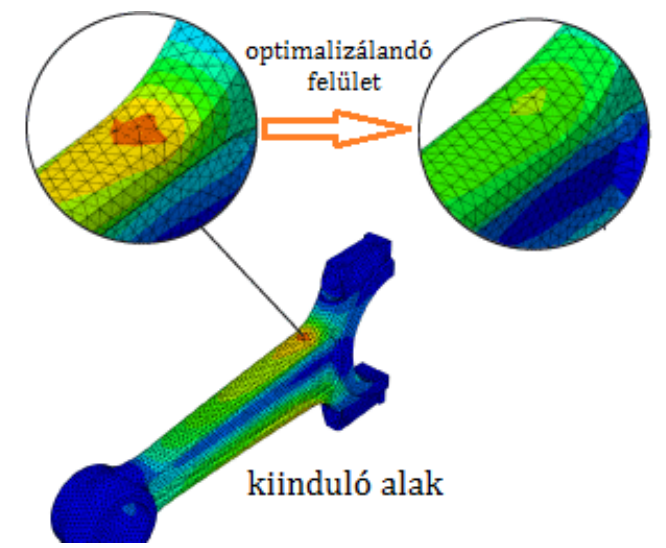

3. ábra. Hajtókar alakoptimalizálási példája 

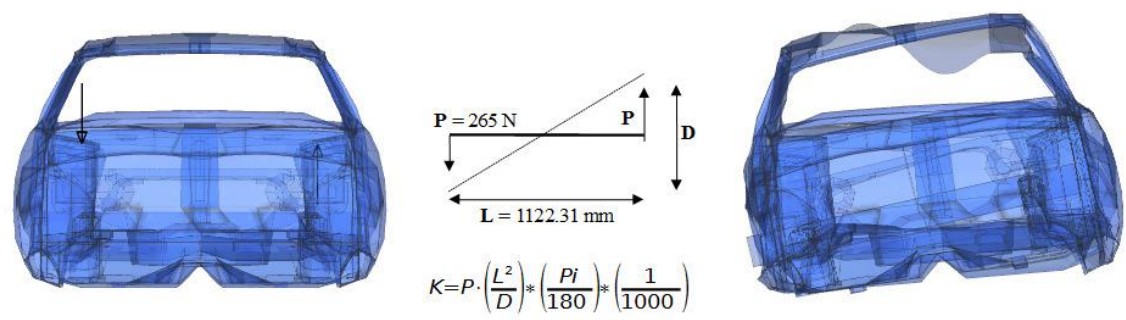

\begin{tabular}{|c|c|c|c|c|c|}
\hline & \multicolumn{2}{|c|}{ Mass } & \multicolumn{3}{|c|}{ Torsional Ricidity } \\
\hline & Added Mass $(\mathrm{Kg})$ & Total Mass $(\mathrm{Kg})$ & $D(\mathrm{~mm})$ & $\mathrm{K}(\mathrm{Nm} / \mathrm{deg})$ & $\mathrm{K}^{\mathrm{z}}(\mathrm{Nm} / \mathrm{deg})$ \\
\hline None (Initial) & 0.00 & 288.50 & 0.0000 & 7369 & 1.00 \\
\hline Topology & 10.09 & 298.59 & 0.6069 & 9599 & 1,30 \\
\hline Sizing & 8.73 & 294.23 & 0.5629 & 10350 & 1.56 \\
\hline Topomety & 4.89 & 293.39 & 0.5077 & 11474 & 1.58 \\
\hline Freeform & 0.71 & 289.21 & 0.4995 & 11663 & 2.00 \\
\hline Freeform \& Topometry & 4.88 & 293.38 & 0.3647 & 15975 & 2.17 \\
\hline & $\square_{\text {Lowest }}^{\text {Highest }}$ & & $\bigoplus_{\text {Lowe }}^{\text {High }}$ & & \\
\hline
\end{tabular}

\section{4. ábra. Jármükarosszéria optimalizálási példája [18]}

Az előzőekben tárgyalt három fő optimalizálási eljárás az Abaqus Tosca szoftvercsomag része. Fontos megemlíteni, hogy az általános célú végeselem rendszerekben a programkód módosítható és bővíthető, azaz például írhatók saját optimalizációs kódok speciális feladatok végrehajtására. A [19] cikkben láthatunk egy példát Python programnyelven íródott optimalizációs algoritmusra (Abaqushoz kapcsoltan).

\section{A feladat megfogalmazása Abaqus végeselem szoftverben}

A szabványos adatformátumoknak köszönhetően a kiinduló geometria könnyen importálható a preprocesszorba, ahol a kezdeti végeselemes szimuláció lefuttatható. Akár több lépésben (Step-ben) is futtathatunk szimulációkat. Ezután a szoftver optimalizációs moduljában hozzáférhetünk az elözőekben bemutatott esetekhez (topology, shape, sizing optimization) továbbá a héjak merevségének növelését célzó ún. bead optimalizációs módszerhez is. Jellemzően a SIMP-módszert használja az Abaqus a topológiai optimalizálás kivitelezésére.

Az optimalizáció egyik sarokpontja az alkalmazott háló minősége, ugyanis az nagyban befolyásolja a futási időt és az eredményeket. Továbbá célszerü magasabb rendủ elemeket használni az optimalizációs eljárás közben fellépő (a geometria változásának hatására kialakuló - pl. locking) esetleges numerikus instabilitások kiküszöbölésére. Érdemes a szimulációs idő csökkentése érdekében a fontosabbnak ítélt tartományokon süríteni a hálót.

A választott módszernek megfelelően kiválaszthatók a tervezési célfüggvények és korlátok (objective functions és constraints), egyesével és kombinált formában is. Megjegyzendő, hogy nem minden eljárásban érhető el minden függvény. Választható függvényként a térfogat/tömeg, alakváltozási energia (mint a szerkezeti merevséget jellemző érték), deformáció, sajátkörfrekvencia, feszültség, tömegközéppont, tehetetlenségi nyomaték, reakcióerők és nyomatékok stb. (az első 5 függvényt használják leggyakrabban a mérnöki gyakorlatban). Sok esetben jól müködik, ha a legbizonytalanabb függvényt írjuk elő tervezési célfüggvénynek, és a kötöttebb függvényeinket 
korlátnak hagyjuk, azaz például, ha a felhasznált anyagmennyiséget szeretnénk megfelezni, akkor érdemes a térfogatot egyenlőtlenséggel elöírni, avagy ha a merevség adott, azt egy elmozdulási korláton keresztük lekötni.

A geometriára vonatkozó megkötéseket is meg tudunk adni, különösen figyelmet szentelve a peremfeltételek és terhelések régióira, leköthetjük (,befagyaszthatjuk”) ezeket a zónákat. Példaként említhetö a felületi nyomás avagy a követő terhelések, amelyek esetben az optimalizálás során bekövetkezö geometriaváltozás hatását figyelembe kell venni (vagy a tervezési tartományon kívül hagyni a szóban forgó felületeket) és például $R A M P$-módszert választani.

A geometriára vonatkozó megkötésként különböző szimmetriatulajdonságokat is elöírhatunk az alkatrész részeire avagy egészére. Méretkorlátok állíthatók be, illetve gyártási (pl. öntésre vonatkozó) korlátok is megadhatók. Ökölszabályként elmondható, hogy a lehető legkevesebb megkötésre törekszünk, ugyanis azok lecsökkentik a megoldásváltozatok számát.

A szimuláció futtatásának utolsó fázisai a geometria simítása és végeredmény kiexportálása utáni kiértékelés a geometria végső módosításival (reengineering).

A szoftver fejlesztése folyamatos, a legtöbb optimalizációs lehetőség az elöző verziókban a statikus feszültséganalízisre vonatkozik, így speciális problémák esetén korlátozottan alkalmazható (például komplex kapcsolt termomechanikai feladatok esetén).

További korlátot jelent, hogy bizonyos függvények csak bizonyos modellezési technikák mellett alkalmazhatók. Itt hozható példaként, hogy a feszültég tervezési korlátként való alkalmazása a vizsgált szoftver verzióban csak 3D kontinuum elemek esetén alkalmazható, síkfeladatok esetén még nem implementálták.

\section{Numerikus példák}

Tekintsünk egy görbe középvonalú rudat, amelynek két szélső keresztmetszetét befalaztuk, a középső harmadát konstans nyomással terheltük, ahogy az az 5. ábrán is látszik. A $0,1 \mathrm{~m}$ vastag rúd külső és belső sugarai rendre $3 \mathrm{~m}$ és $4 \mathrm{~m}$. Hasonló görbe középvonalú rudak mechanikai problémáival számos cikk foglalkozik, példaként hozható a [20,21], amelyek a stabilitásvesztéssel, avagy [22] amelyek a feszültséganalízisével foglalkoznak.

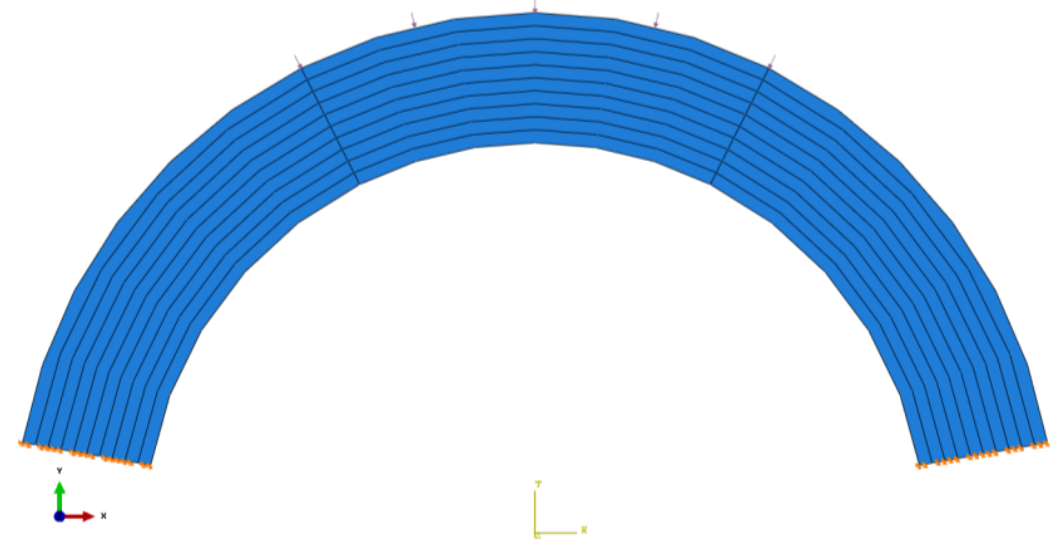

5. ábra. A kiinduló geometria a peremfeltételekkel és terhelésekkel

Jelen példában egy funkcionálisan gradiens anyagú rudat vettünk, amelynek anyagjellemzői a radiális koordináta $(r)$ függvényében változtak az alábbi függvénynek megfelelően: 


$$
\begin{aligned}
& E(r)=\left(E_{2}-E_{1}\right)\left(\frac{r-a}{b-a}\right)^{n}+E_{1}, \\
& v(r)=\left(v_{2}-v_{1}\right)\left(\frac{r-a}{b-a}\right)^{n}+v_{1},
\end{aligned}
$$

továbbá

$$
E_{1}=210 G P a, E_{2}=310 G P a, v_{1}=0.3, v_{2}=0.24, n=0.2,
$$

ennek a feladatnak a megoldása a [22] cikkben ismertetett összefüggéseivel a feszültség és elmozdulásmezője meghatározható lenne. A végeselemes programrendszerben a funkcionálisan gradiens anyagok jellemzőinek megadására több lehetőség áll rendelkezésre. Használhatók felhasználói szubrutinok, avagy szekcionálási technikák is. Ezen utóbbi módszerben homogén rétegekere bontjuk a szerkezetet, amelyeken belül az anyagjellemzők értékeinek valamilyen módszerrel diszkrét értékeket adunk (erről olvashatunk pl. [23, 24] cikkekben is). Jelen példában a rudat 10 rétegre osztottuk és az anyagjellemzőket a rétegek közepén számított értékeikkel adtuk meg. Az első esetben, amit a 6 . ábra szemléltet a térfogatot $30 \%$ alá szerettük volna csökkenteni, miközben a merevséget maximalizáljuk, azaz az alakváltozási energiát minimalizáljuk.

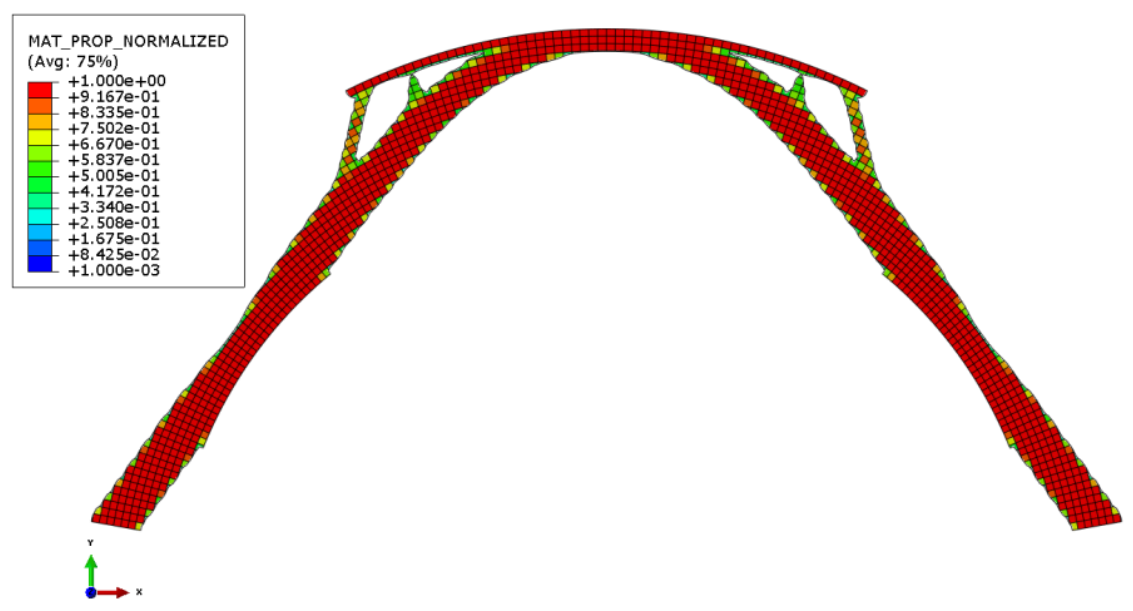

\section{6. ábra. Az első optimalizálási eset - merevség maximalizálása}

A második esetben a von-Mises-féle redukált feszültségeket akartuk a megengedett $313 \mathrm{MPa}$ feszültségértékhez igazítani, miközben a tömeg csökkentése és a deformációk minimalizálása volt a cél. Ehhez a geometriát módosítani kellett, ugyanis ezt a rendelkezésre álló verzió csak 3D elemek alkalmazása mellett engedte. Az eredményt a 7. ábra mutatja. Ebben az esetben szimmetriafeltételek miatt csak a szerkezet felét vizsgáltuk, így a szimulációs idő csökkenthető. Fontos megjegyezni, hogy amennyiben az anyageloszlás hatását szeretnénk vizsgálni, arra már csak a VEM rendszer programozásán keresztül van lehetőségünk. Ekkor releváns kérdés lehet például az $n$ paraméter értékének megválasztása, amely az előzőekben ismertetett esetet tekintve egy klasszikus egyparaméteres optimalizálási feladat. Bonyolultabb terhelési eseteket vizsgálva esetleg több irányba is változhat az anyagjellemzők függvénye, ami bonyolítaná a parametrikus optimalizálást. A teljes termomechanikai feladat megoldásához robusztusabb megoldóra van szükségük, amely kezelni tudja a kapcsolt hörugalmas egyenletrendszert is. 


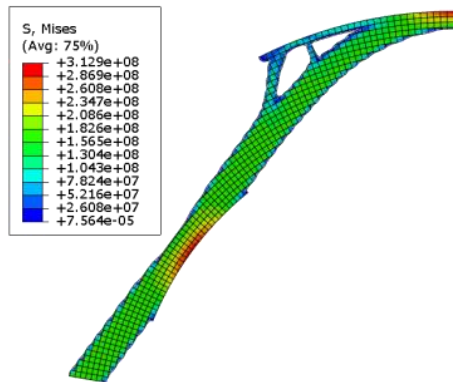

7. ábra. A második optimalizálási eset-feszültségek korlátozása

A harmadik esetben anizotrop, kompozit anyagból készült rudat vizsgáltunk. A kompozitok egyik fö előnye, hogy kiváló mechanikai tulajdonságaik mellett kis tömegük miatt preferálják őket. Az általános célú végeselem szoftverek nagy előnye, hogy konstitutív egyenletek széles skálája érhető el bennük. Szálerősítéses (ortotróp) anyagok esetén a kísérleti eredményeinket közvetlenül megadhatjuk mérnöki jelölésmódban is [16]. A grafit-epoxi kompozit anyagjellemzői:

$$
E_{1}=132 \mathrm{GPa}, E_{2}=10,8 \mathrm{GPa}, G_{12}=5,7 \mathrm{GPa}, G_{23}=3,4 \mathrm{GPa}, v_{23}=4, v_{12}=0.24,
$$

ahol az 1-es irány a kitüntetett szálirány. Ebben az esetben négy szimulációt futtattunk. Az első két esetben a derékszögü koordináta-rendszer 5. ábrának megfelelő $x$, majd $y$ irányaiba, majd az utolsó két esetben pedig hengerkoordináta-rendszert használva a radiális, majd a szögkoordináta irányába vettük fel az 1 jelü irányt. A célfüggvény az alakváltozási energia volt, amelynek minimalizálására törekedve csökkenttettük a térfogatot $30 \%$ alá. Az első két eset a feszültségek szempontjából kedvezőtlenebbnek bizonyult a hengerkoordináta-rendszerbeli párjaikkal szemben. A 8. ábrán látható a derékszögü koordináta-rendszer $y$ irányába orientált anyag esete, ahol az tervezési ciklusokban láthatjuk a térfogat (kék görbe) és az alakváltozási energia (piros görbe) alakulását. Ekkor $100 \mathrm{MPa}$ felett volt a redukált feszültség maximum értéke.

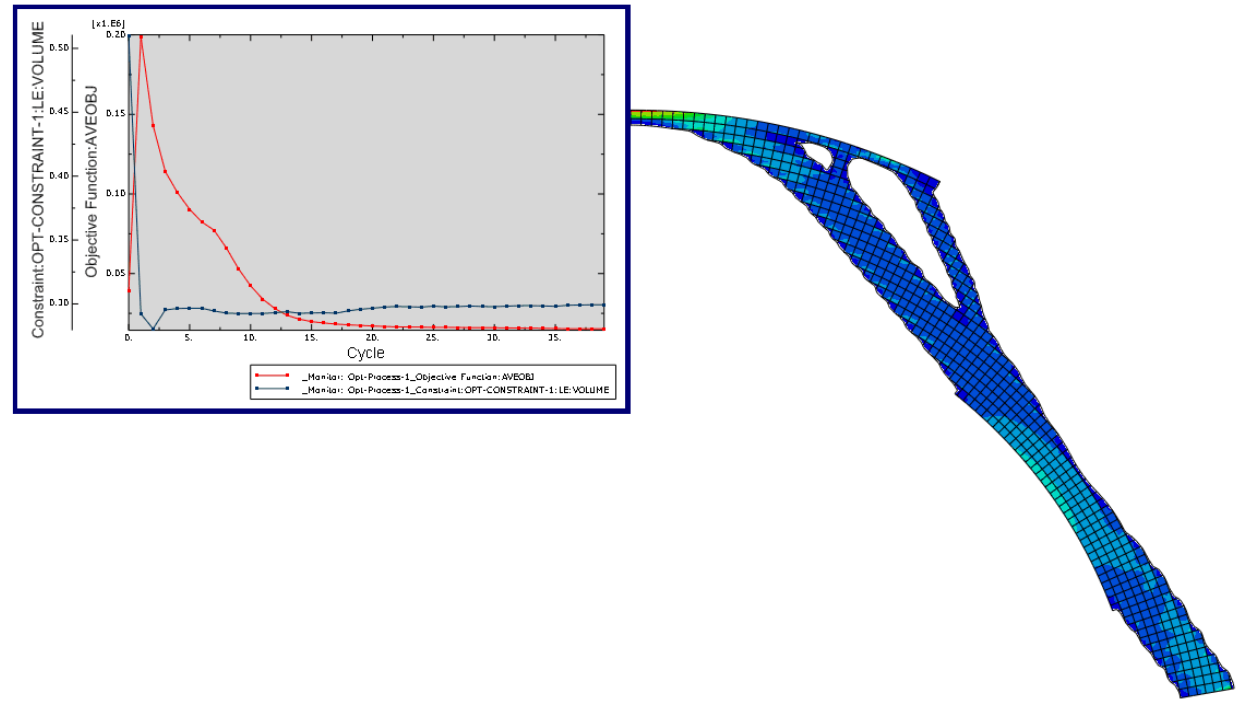

8. ábra. A harmadik optimalizálási eset alakulása a tervezési ciklusokban az optimalizált alak feszültségeloszlásával 
Végül pedig a 9. és 10. ábrák mutatják a hengerkoordináta-rendszerben kapott eredményeinket. Látható, hogy a legkedvezőbb esetben, radiális szálirány esetén a maximális von-Mises feszültségek $85 \mathrm{MPa}$ alatt voltak, míg a rá erőleges szálirányú elrendezésnél $134 \mathrm{MPa}$-ra nőttek 70\%-os térfogatcsökkentés esetén. Az optimalizált alakok a simítási lépésekkel kiexportálhatók és módosíthatók a végleges alakjukra.

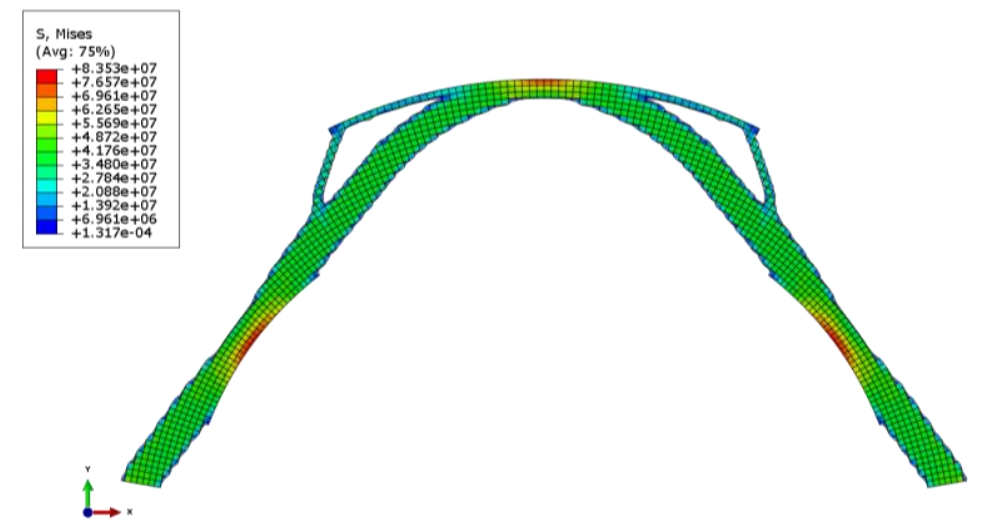

9. ábra. A negyedik optimalizálási eset - radiális szálirány melletti feszültségeloszlás

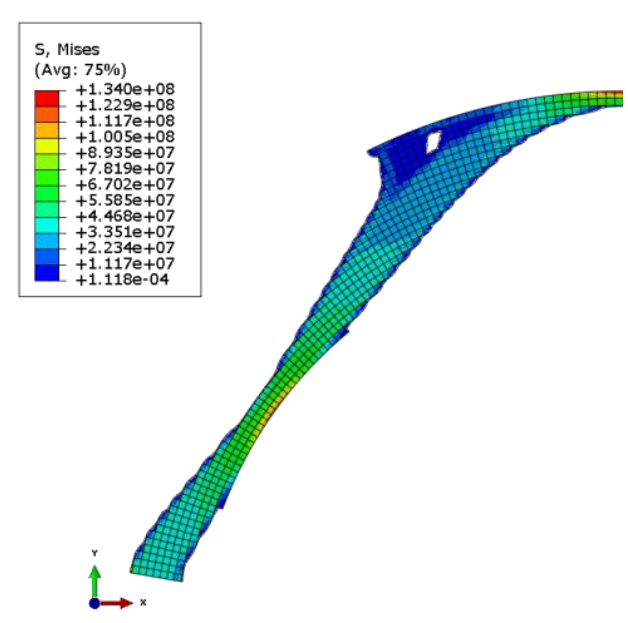

10. ábra. Az ötödik optimalizálási eset - tangenciális szálirány melletti optimalizált alak a feszültségeloszlással

\section{4. Összefoglalás}

A dolgozat az Abaqus kereskedelmi végeselem szoftver optimalizálási lehetőségeinek vizsgálatával foglalkozott. Az optimalizálási feladatok matematikai megfogalmazása után a problémamegoldás VEM szoftverbeli sajátosságai lettek ismertetve. Majd funkcionálisan gradiens és kompozit anyagú, görbe vonalú rudak egyszerü topológiai optimalizálási példáin keresztül mutattuk be a módszer Abaqus szoftverbeli alapjait és alapvető jellegzetességeit. 


\section{Köszönetnyilvánítás}

A cikkben ismertetett kutató munka az EFOP-3.6.1-16-2016-00011 jelü „Fiatalodó és Megújuló Egyetem - Innovatív Tudásváros - a Miskolci Egyetem intelligens szakosodást szolgáló intézményi fejlesztése" projekt részeként - a Széchenyi 2020 keretében - az Európai Unió támogatásával, az Európai Szociális Alap társfinanszírozásával valósul meg

\section{Irodalom}

[1] Bendsoe, M. P., Sigmund, O.: Topology optimization: theory, methods, and applications, Springer Science and Business Media, 2013 https://doi.org/10.1007/978-3-662-05086-6

[2] Johnsen, S.: Structural topology optimization: Basic theory, methods and applications, Springer, 2016.

[3] Gibson, I., Rosen, D., Stucker, B.: Additive manufacturing technologies, Springer, New York, 2010, ISBN 978-1-4419-1119-3 https://doi.org/10.1007/978-1-4419-1120-9

[4] Erdősné Sélley, Cs., Gyurecz, Gy., Janik, J., Körtélyesi, G.: Mérnöki optimalizáció, Typotex kiadó, 2012, ISBN 978-963-279-538-6.

[5] Liu, J., Ma, Y.: A survey of manufacturing oriented topology optimization methods, Advances in Engineering Software, 100, (2016) pp. 161-175.

https://doi.org/10.1016/j.advengsoft.2016.07.017

[6] Sigmund, O., Maute, K.: Topology optimization approaches, Structural and Multidisciplinary Optimization, 48(6), (2013) pp. 1031-1055. https://doi.org/10.1007/s00158-013-0978-6

[7] Brackett, D., Ashcroft, I., Hague, R.: Topology optimization for additive manufacturing, In Proceedings of the Solid Freeform Fabrication Symposium, Austin, TX, Vol. 1, (2011) pp. 348-362.

[8] Zuo, W., Saitou, K.: Multi-material topology optimization using ordered SIMP interpolation, Structural and Multidisciplinary Optimization, 55 (2), (2017) pp. 477-491. https://doi.org/10.1007/s00158-016-1513-3

[9] Liu, J., Gaynor, A. T., Chen, S., Kang, Z., Suresh, K., Takezawa, A., Cheng, L.: Current and future trends in topology optimization for additive manufacturing, Structural and Multidisciplinary Optimization, 57 (6), (2018) pp. 2457-2483.

https://doi.org/10.1007/s00158-018-1994-3

[10] Paulino, G. H., Silva, E. C. N.: Design of functionally graded structures using topology optimization, In Materials Science Forum, Vol. 492, (2005) pp. 435-440, Trans Tech Publications, Ltd. https://doi.org/10.4028/www.scientific.net/MSF.492-493.435

[11] Radman, A., Huang, X., Xie, Y. M.: Topology optimization of functionally graded cellular materials, Journal of Materials Science, 48 (4), (2013) pp. 1503-1510. https://doi.org/10.1007/s10853-012-6905-1

[12] Taheri, A. H., Suresh, K.: An isogeometric approach to topology optimization of multi-material and functionally graded structures, International Journal for Numerical Methods in Engineering, 109 (5), (2017) pp. 668-696. https://doi.org/10.1002/nme.5303

[13] Sigmund, O., Torquato, S.: Design of smart composite materials using topology optimization, Smart Materials and Structures, 8 (3), 365., (1999)

https://doi.org/10.1088/0964-1726/8/3/308

[14] Blasques, J. P., Stolpe, M.: Multi-material topology optimization of laminated composite beam cross sections, Composite Structures, 94 (11), (2012) pp. 3278-3289.

https://doi.org/10.1016/j.compstruct.2012.05.002 
[15] Yan, X., Huang, X., Zha, Y., Xie, Y. M.: Concurrent topology optimization of structures and their composite microstructures, Computers \& Structures, 133, (2014) pp. 103-110. https://doi.org/10.1016/j.compstruc.2013.12.001

[16] Abaqus Standard User's Manual Version 6.13, 2017.

[17] Szabó, K., Hegedűs, Gy.: A generativ tervezést támogató szoftverek rövid áttekintése, Multidiszciplináris tudományok, 10 (3), (2020) pp. 328-337. https://doi.org/10.35925/j.multi.2020.3.39

[18] Leiva, J. P.: Structural optimization methods and techniques to design efficient car bodies, In Proceedings of International Automotive Body Congress, 2014.

[19] Zuo, Z. H., Xie, Y. M.: A simple and compact Python code for complex 3D topology optimization, Advances in Engineering Software, 85, (2015) pp. 1-11. https://doi.org/10.1016/j.advengsoft.2015.02.006

[20] Kiss, L.: In-plane buckling of rotationally restrained heterogeneous shallow arches subjected to a concentrated force at the crown point, Journal of Computational and Applied Mechanics, 9 (2), (2014) pp. 171-199. https://doi.org/10.32973/jcam.2019.003

[21] Kiss, L., Szeidl, Gy.: Nonlinear stability analysis of FGM shallow arches under an arbitrary concentrated radial force, International Journal of Mechanics and Materials in Design, 16 (1), (2015) pp. 91-108. https://doi.org/10.1007/s10999-019-09460-2

[22] Gönczi, D.: Analysis of a curved bimetallic beam, Journal of Computational and Applied Mechanics, 14 (1/2), (2019) pp. 41-51. https://doi.org/10.32973/jcam.2019.003

[23] Gönczi, D.: Thermoelastic analysis of thick-walled functionally graded spherical pressure vessels with temperature-dependent material properties, Journal of Computational and Applied Mechanics, 12 (2), (2017) pp. 109-125. https://doi.org/10.32973/jcam.2017.008

[24] Gönczi, D.: Analysis of rotating functionally graded disks with arbitrary material properties, Acta Technica Corviniensis, Bulletin of Engineering, 4, (2018) pp. 1-6. 